only traces, memory, confusion, awe, and a silent resolve.

Yesterday, I visited a dying man. He was in the palliative care unit, dying of a prostate cancer that wouldn't leave him alone. Its latest injustice, only months ago, was perpetrated on his spinal cord. He is now paraplegic, confined to a wheelchair. He revisited his life for me and some classmates of mine. Sixty-two years he has lived. Thirteen of those years he has had cancer. But he has no regrets, a loving wife and daughters, a passion for life. His youngest daughter is pregnant with his first grandchild, a girl. Her due date is July 23, six months and nine days from today. His modest yet ambitious goal is to be alive to hold his granddaughter. He doesn't consider himself dying. But he also doesn't know if he'll make it. He doesn't ever expect to return home.

He spends his days reading and entertaining visitors. His family visits whenever they can. The hardest thing to deal with is the difficulty his condition has placed on his family. The second hardest thing to deal with is his sudden immobility. He can't walk, he can't take care of himself, he can't change position in his bed on his own. He hates depending on others. He used to travel often. He stayed at his job as a manager of an international company until three years ago. Now he lives to make it to July 23.
A few months ago, he had an MRI. As he lay with his face inches away from the off-white plastic, with the machine's gears grinding loudly, he drifted off, and relived his trip to the island of Santorini, in Greece. In his mind, as he relived it all, he could walk. He lived without fear, and walked with his wife, who he could hold, and be free with, and make love to. In that moment, he captured déjà vu, and used it to live forever, for a small while.

\section{Ariel Lefkowitz BA BSc}

Class of 2013

McGill University

Montréal, Que.

CMAJ 2011. DOI:10.1503/cmaj.110890

\title{
Searching for the value of the imperfect
}

\author{
The Boy In The Moon: A Father's Search \\ for his Disabled Son \\ lan Brown \\ Random House of Canada Ltd.; 2009.
}

$\mathrm{W}$ alker Henry Schneller Brown is a child of modern medical science. Born with the rare genetic condition, cardiofaciocutaneous syndrome, he is medically complex and fragile and would not have survived his first months of life had nature been left to take its course. Now, at 13 years of age, Walker functions like an 18 to 24 month old. The Boy in the Moon, written by Walker's father, Globe and Mail journalist Ian Brown is the deeply moving account of a father's search for his disabled son. Brown likens Walker to the man in the moon "you see the face of the man in the moon, yet you know there's actually no man there. But if Walker is so insubstantial, why does he feel so important?" His search is one "for the value of a life ... lived in the twilight and often in pain and ... the cost of his life to those around him?"

Brown treats readers to an enlightened account of human potential and worth. While conveying the gravity of Walker's life and life with him could overwhelm a reader, in the gifted hands

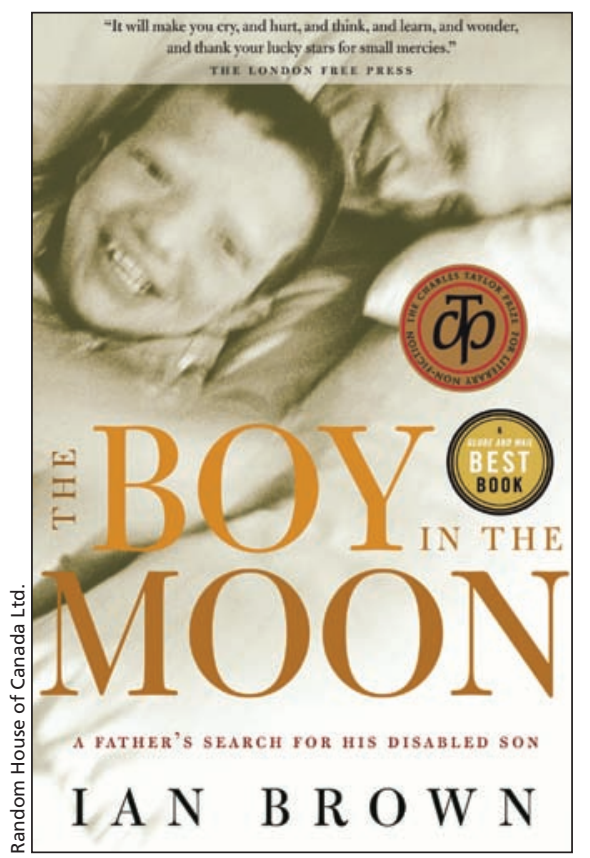

of Brown the reader feels, but does not suffer his anguish. Through juxtaposing accounts of his despair with quirky, sometimes black humour and poignant moments between father and son, Brown lifts us and in so doing draws us deeper into his search for the value of an imperfect life. Brown's style is exemplified in the following account: A neuroradiologist shows Brown an MRI contrasting a normal corpus callosum to Walker's;
Walker's was just a fraction of the normal width. Brown is devastated, "Its hard to describe how quickly it crushed me ... "Continuing, the physician explains, "So that means there's a lack of connectivity in your son's brain." Recognizing that ... "the corpus callosum is the information highway of the brain," Brown concludes that "... Walker's brain subscribed to a crappy Internet service that constantly broke down and misdelivered messages ..." The MRI revealed nothing about Walker that Brown had not already known, but through this offbeat account Brown ponders the profound: "Without a knowable brain, was Walker a knowable boy? If he wasn't what was his value?"

Many of the physicians Brown encountered were confounded by Walker's case and distanced themselves from him and their inability to offer a cure. Others like Paul Wang a developmental pediatrician and cardiofaciocutaneous syndrome researcher from Philadelphia's Children's Hospital, admitted the limitations of medicine, and engaged in Brown's search for meaning. Wang delivers the devastating diagnosis of significant developmental delay and the necessity for life-long support, but doesn't conclude the interview, instead he asks for questions. 
Brown queries whether he will ever be able to explain to Walker about the profound peace that the family's remote northern vacation spot brings him [Walker]. While Wang admits that it is unlikely that Walker would respond to such an explanation, he continues, "But ... it sounds like he already understands it. ... The Buddhists say the way to enlightenment, to pure being, is by getting your mind out of the way. I'm not trying to be trite, but Walker already knows how to do that ... in that way he's already miles ahead of us." Wang suggests there is something uniquely valuable about Brown's Boy in the Moon; he provides an insight into how Walker's mind might work, and importantly, his place among the rest of us.

Through his investigative visits to prominent genetics research laboratories and clinics, Brown learns the limits of medical genetics. In doing so, he takes to task knowledge transfer efforts that simplify genetic cause and effect relationships. "Does an oversimplified model of how a human being comes to be result in an oversimplified model of what a human being is?" While seemingly disillusioned with the science of medical genetics, Brown unexpectedly learns something more valuable that facilitates his search for meaning. "Genetic tests are a way to eliminate the imperfect, and all the pain and agony that comes with that imperfection. ... Now that I know Walker, I am relieved there was no such test ... because on his good days, Walker is proof of what the imperfect and the fragile have to offer; a reminder that there are many ways to be human," a sentiment he found echoed by physician, Bruce Blumberg, a geneticist on the team that identified cardiofaciocutaneous syndrome. Blumberg described the problem to Brown as: "... our unwillingness to accept that a handicapped life has real value ... The trick is to give up the idea of the potential child and accept the actual child ... We're arrogant enough to believe that sentience is all that counts. A sequoia is not a sentient being, but they count. There is nothing more magnificent ... It isn't just great minds that matter, its great spirits too ..."

Brown's search for meaning takes him to medical specialists, to other families of children with cardiofaciocutaneous syn- drome, and even to Jean Vanier's L'Arche communities for adults with intellectual disabilities. But ultimately, it is Walker himself who answers his father's questions. Walker shows him “... what I would never have seen without him — his capacity to make a passing moment memorable, and my capacity to appreciate its significance. ... I have begun to simply love him as he is, because I have discovered I can; because we are who we are, weary dad and broken boy, without alteration or apology, in the here and now. The relief that comes with such a relationship still surprises me." A relief we might all come to feel if like Brown, we try " ... to step from time to time into Walker's world ... to face my fear of the broken people who are the Other — not to fix them or even save them, but merely to be with them until I stop wanting to run away." Reading The Boy in Moon brings us one step closer to doing so.

\section{Elizabeth Skarakis-Doyle PhD}

Professor

Faculty of Health Sciences

University of Western Ontario

London, Ont.

CMAJ 2011. DOI:10.1503/cmaj.101477

\section{More Humanities online}

\section{Books}

\section{The Professional Guinea Pig: Big Pharma and the Risky World of Human} Subjects, by Roberto Abadie (Duke University Press, 2010). Abadie, an anthropologist, penetrates the corps of professional and semi-professional human test subjects to uncover often shocking accounts of their lives. He poses questions about who these people are and what drives them, as well as the most disturbing question of all: Can we trust the information that comes out of these trials? - Alan Cassels MPA, Victoria, BC

The Yacoubian Building, by Alaa Al-Aswany (Fourth Estate; 2007). As a Canadian of Egyptian descent, our reviewer was inundated with questions during the recent revolution. He referred his colleagues to Al-Aswany, whose best-selling novel about the residents of an apartment building offers a microcosm of contemporary Egyptian society - and its malaise. - Tarek Abd el Halim BSc, Toronto, Ont.

Contesting Aging \& Loss, Janice E. Graham and Peter H. Stephenson, editors (University of Toronto Press; 2010). These authors enjoin physicians to listen to their elders and park their preconceptions at the door. - A Mark Clarfield MD, Ben-Gurion University, Negev, Israel

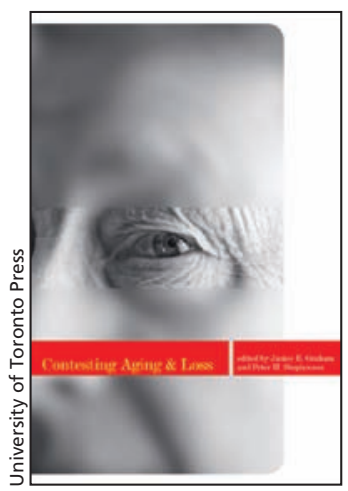

\section{Essay}

The cost of living: tracing the supply chain for superconductors in MRI machines. When the Canada Science and Technology Museum received a 20-ton magnetic resonance imaging machine in 2005, a curator set about researching its origins. His efforts afford a surprising glimpse into the elaborate manufacturing world of modern medical technology that includes environmental concerns, national security issues and radiation hazards to miners. - David Pantalony PhD, Ottawa, Ont.

CMAJ 2011. DOI:10.1503/cmaj.111198 cmaj.ca 